\title{
Teachers' Effectiveness in Developing Constructive Learning in Civic Education
}

Nani Nuraeni, ${ }^{1}$ Dinie Anggraeni Dewi ${ }^{2}$

Prodi PPKn FKIP Universitas Islam Nusantara

nani_aeni.@yahoo.co.id ${ }^{1}$, anggraenidewidhinie@gmail.com ${ }^{2}$

\begin{abstract}
ABSTRAK
Penelitian ini dilatarbelakangi pentingnya kompetensi pedagogik guru dalam mengembangkan tugas profesinya yakni mengembangkan pembelajaran untuk sebesarbesarnya mencapai hasil belajar peserta didik. Hal ini hanya mungkin dapat dicapai apabila guru efektif melibatkan konstruk berfikir peserta didik dalam proses pembelajarannya, yakni mempertimbangkan aspek waktu yang tersedia untuk memperoleh capaian hasil belajar optimal. Tulisan ini merupakan hasil penelitian mendalam terhadap guru Pendidikan Pancasila dan Kewarganegaraan yang efektif mengembangkan pembelajaran konstruktif dan menunjukkan hasil positif terhadap kualitas belajar peserta didiknya pada jenjang pendidikan dasar Sekolah Menengah Pertama. Untuk memperoleh makna tujuan penelitian, digunakan pendekatan kualitatif dan kuantitatif secara terpadu. Hasil penelitian efektifitas guru dalam mengembangkan pembelajaran konstruktif ditunjukkan dengan upayanya untuk menciptakan suasana yang produktif dalam proses belajar dan melibatkan pola interaksi pembelajaran variatif untuk menggali keterampilan berfikir peserta didik pada tingkat tinggi.
\end{abstract} Kata kunci: efektifitas guru, pembelajaran konstruktif, kualitas hasil belajar

\begin{abstract}
The background of this study is the importance of teachers' pedagogical competence in developing their professional duties by developing the learning activities as many as it could to achieve the learning outcomes from the learners. This is only possible if the teachers involve the thinking construct of learners in the learning process effectively by considering the available time aspect to gain optimal achievements in learning outcomes. This paper is the result of an in-depth research of the civic teachers who effectively develop constructive learning and show positive results in the learning quality of their students in the primary education level of junior high school. In order to obtain the meaning of the research objective, the researcher employs an integrated qualitative and quantitative approaches. The result of the study found that teachers' effectiveness in developing constructive learning is showed by an attempt to create a productive learning atmosphere in the process of learning and to involve various learning interaction patterns to explore learners' thinking skill in a high level.
\end{abstract} Keywords: teachers' effectiveness, constructive learning, quality of learning outcomes

This work is licensed under the Creative Commons Attribution-ShareAlike 4.0 International License. (C2017 by the author(s).

Received: April 122017

Revised: August 42017

Accepted: August 82017

\section{INTRODUCTION}

Teachers have an important role in achieving educational success. If education is seen as an effort to develop individual maturity (Langeveld, 1980); teacher is a mature person who has an ability to develop his students' responsibility. If education is seen as a process of experiences (John Dewey); teacher, then, is an important instrument who helps fulfilling the content of spiritual growth, individual 
mental, so that it develops optimally in each step of the growth. An effective teacher, while developing her educational role, will try to optimize his educational tasks in order to pursue the predetermined outcomes.

Philosophically, sociologically, and psychologically, learning should focus on the learners (child-centered), not on the teacher (teacher-centered). However, it does not mean that teacher does not have roles and lets the learners' needs become inefficient. Constructive learning means giving opportunities for learners to do active learning, involves their minds, construct/build their own knowledge (John Dewey, Jerome Brunner, Piaget)

In educational context, the skill of thinking is a basic competence that must be built and developed in the process of learning. The skill of thinking becomes a power to be able to construct the knowledge that they acquire. Applying constructive learning in civic education is a-must. It is due to the goal of education in which it puts responsibility and participation of the society as the ends. The goal of civic education involves the aspect of thinking skill (constructive) and relates it with the reality of a social life (contextual). Branson (1998) said that there are three components of objective in civic education: civic knowledge, civic skills, and civic dispositions. Those components of objective involve aspect of understanding civic education issues, civic skills involving intellectual skills (critical thinking and creative thinking) and participation skills which are responsible and effective in political process and civil society, also developing good personal and public characters in the society.

Constructive learning will obtain optimal result only if effective teachers develop the learning. An effective teacher will consider aspect of time, available for his learners in achieving the demands of obtaining optimal result. Empirically in learning practice implemented for junior high school level in Bandung, West Java which have implemented learning-based curriculum using.

Scientific, it is found that there are teachers who are not optimally developing their learning activity yet, so that it impacts the quality of learning outcomes of learners. However, the researcher still found the teachers who effectively develop their learning activity and has a positive tendency towards the quality of learning outcomes of learners. Accordingly, this paper aims to describe the characteristic of the effectiveness of teachers in developing constructive learning along with the support to the quality of learning outcomes of learners in learning civics at junior high school level.

\section{RESEARCH METHOD}

This study employs mixed method approach, both qualitative and quantitative research, in the form of sequential exploratory (Creswell, 2010; Sugiyono, 2011). The quality of main research lies in the data that is qualitative (teacher's effort to develop constructive learning) and then strengthened with the support of data that is quantitative (learners' learning outcomes). Qualitative approach is considered effective to obtain the purpose of this study, considering the data needed requires the analysis or assessment that is contextual. The role of the researchers is as an instrument to dig deeply, analyze the whole phenomenon that 
emerges and find a meaningful value by understanding some variables that appear in the process of learning activities. The sample of research is determined purposively, that is 10 teachers who have "good" qualification from 6 State Junior High School in Bandung West Java, in class learning setting. School target being studied is public schools (Public Junior High-School) that use the same curriculum and has a good reputation/favorite in the community's assessment.

The indicators of instrument for measuring cognitive aspects, as key elements in this study, include: The ability to concentrate on the learning process, consists of these aspects: mind-focusing while learning; the seriousness of paying attention to the material; Not doing anything else while learning; 2) The ability to remember the material being studied, comprising the aspect of: explaining concepts that have been studied correctly, showing facts and data that have been studied correctly, asking questions in accordance with the concept of the material being studied. 3) The ability to ask question, comprising the aspect of: able to ask questions that contain problems, whether the question is logical or not, the relevance to the material being studied; 4) The ability to propose logical ideas, comprising the aspect of: whether the idea/opinion is logical or not, the relevance to the problem/main idea being proposed, the level of depth \& width of thinking; 5) The skill of contextual thinking comprising the aspect of: connecting the material with the reality in society, exploring facts from social reality in accordance with the material being studied; 6) The ability to propose new/original ideas in problem solving, comprising the aspects of: producing the ideas of his own thinking, exploring the ability to solve problems that are different from those which are already existed, exploring the imaginative abilities. 7) Learning achievement (the value of learning outcomes), learning outcomes assessed by the teacher.

In qualitative research, the researcher acts as a plan maker, executor, data collector and data analyzer. In the process of data collection, the researcher categorizes the data according to an appropriate category. The researcher reflects and interprets the data acquired in order to understand the data. Qualitative data collection is carried out by using the technique of observation, interview, and documentation analysis. Qualitative data analysis is carried out through data reduction phase, data presentation, drawing conclusion, and verification (Miles \& Huberman: 1992).

While quantitative data collection uses the technique of written test in the form of essay (cognitive aspects) and questionnaire (affective and skill aspects). Quantitative data analysis employs ordinal data descriptive analysis with the percentage (\%) statistical data processing.

The support of learning outcomes ability that is acquired classically by the respondents are indicated by the scale of: very high (86-100), high (71-85), medium (56-70), low (<_ 55) (the assessment accommodation is based on the assessment guidance for junior high- school; Ministry of Education and Culture, 2015).

\section{RESULT}

\section{Civics Teachers' Efforts in Developing Constructive Learning}

The picture regarding the efforts of Civics teachers in developing constructive learning are gained through observation result in the learning process and an in- 
depth interview on certain aspects that require reinforcement towards the value of pedagogical competence. The results of this research are elaborated as follows:

a. Early learning activities, teachers create an atmosphere that encourages learners to be actively involved in the learning process, through the following process: 1). Involve the learners' experiences as a reference in developing the learning activity; 2). Convince the crucial value of conceptual material being learned for they own sake; 3). Show the steps of learning activities of learners, so that learners understand the learning tasks that will be lived during the learning took place. 4). Giving learning guidance so that the learners actively question the things that they do not understand

b. Teachers explore the ability of learners to ask productively, through the following ways:1). Ask learners to read the text regarding the content of the study materials and ask students to come up with questions; 2). Give a brief description of the material in writing form, learners are asked to raise questions; 3). Use a media/display containing the problem/case as a stimulant to think to arouse the question of the learner; 4). Give appreciation to the ideas/notions of learners in raising questions.

c. Develop thinking skills at high level (analyze, evaluate and create). The teacher's efforts are done through: 1). Learning stimulation with meaningful questions; 2). raise questions with the stimulation of contextual problems; 3). raise questions that are testing and judgmental; 4). Use choice statements with logical and contextual reasons; 5). Ask learners to assess and give their opinion on controversial cases; 7). Develop learning activity with an inquiry process approach; 8). Develop learning activity with a scientific approach; 9). Use an evaluation instrument that measures the process of high-level thinking skills (analysis, evaluation, creative); 10). Encourage reflective thinking to generate creative ideas in solving problems.

d. Build a high sensitivity to the need for effective and productive learning, shown by the following: 1). Teachers have a strong understanding of the psychological characteristics conditions of their students; 2). Teachers have a strong understanding of the curriculum content that they need to implement in their learning activity; 3). Teachers have a high responsibility to teach their students independently; 4). Ensuring that the ability to learn independently will result in high achievement; 5). Teachers explore the importance value of the skills needed by the learners in relation to the material being learned; 6). Use the strategy/ learning model that involves the thinking activity and working in the learning process; 7). Build comfortable and enjoyable learning activities for learners; 8). Perform evaluation with instrument that is relevant to learners' condition, factual and conceptual integration.

e. Develop learners' high curiosity by the following ways: 1). Condition learners to understand their learning objectives; 2). learning stimulation with readings containing new (unread) ideas, which contain clarity of concepts and learning challenges; 3). Learning stimulation using meaningful and engaging media, and challenging case content, effectively use media of communication technology; 4) learning stimulation with stories containing conflicts of value 5). Develop 
learning by presenting the source of learning "expert" in the classroom, in accordance with the topic discussed; 6). Develop learning activity with inquiry and collaborative project activities; 7). Develop cooperative learning that enables the involvement of individual learning participation in high groups.

f. Drill students' learning ability to produce original / new thinking ideasthrough the following ways: 1). Make sure that every individual has the ability to think about finding ways to solve problems; 2). Stimulate learning with examples of creative work; 3). ask learners to write down their new ideas in solving conflicts or specific cases; 4). Develop learning activity with the mind mapping concept and teachers ask an explanation about it; 5). Give appreciation of any original work or idea generated by the learners through their learning activities no matter how small it is.

g. Conducting a diagnosis regarding learning difficulties of learners and simultaneously convey the design to find a solution, in the following ways: 1). Observe (observation) learners' behavior during the learning process in the classroom: 2). Measure, assess and follow up the achievement of learners' learning outcomes; 3). provide test results/learning results and provide guidance for the need to improve learning achievements; 4) calling a passive and problematic student in learning, personally; 5). Conduct an in-depth interview to find problems that interfere with their learning activities; 6). Provide suggestions and motivations to solve problems and be ready to help the difficulties they face related to the importance of learning.

h. Acting as a constructive learning facilitator, it is showed as follows: 1) able to position themselves as educator, mentor and problem solver of their learners; 2) have an attitude that is open and not discriminating against the students; 3 ) have a positive attitude to advance the potential of learners optimally; 4) appreciate learners' responses in learning no matter how small it is; 5) not easily getting emotional in facing the problem of learners in the learning process; 6) in the process of learning, the teachers build a harmonious communication with the learners.

\section{The Support of Civics Teacher Effectiveness in Developing Constructive-Based Learning}

\section{a. Support on The Achievement of Cognitive Learning Outcomes}

The results of research show that the effectiveness of teachers in developing constructive learning on civics, give a positive support for the achievement of learners' cognitive outcome that is shown with a very high (ST) ability and high (T) ability about $81 \%$ (ST 29\% \& T 52\%) in the ability to concentrate on the learning process and the ability to remember the material that has been studied ST $27 \%$ \& $54 \%$. The other achievement of cognitive learning outcomes gain very high scores on aspect of ability in proposing logical opinion/ideas $78 \%$ (ST 24\% \& T 54\%); contextual thinking ability that connects with problems in real life environment $80 \%$ (ST 22\% \& T 58\%); ability to propose new/original ideas in problem solving 75\% (ST $21 \%$ \& T 54\%); ability to ask questions 79\% (ST 4\% \& T 55\%) and very high score and high score in learning achievement $80 \%$ (ST $18 \%$ \& T $62 \%$ ).

\section{b. Support on The Achievement of Effective Learning Outcomes}


The result of the research shows that the effectiveness of civics teacher in developing constructive learning has a positive support for the achievement of affective learning outcome, is shown by the very high and high ability on the aspects of: high learning seriousness in the classroom $(81 \%)$ and high encouragement aspect to be honest to behave $(82 \%)$. While other aspects are very high and high: curiosity in learning (80\%); High courage to express opinion (79); Confidence to change attitudes to be better (79\%); and has a high learning challenge, indicated by a range of values $(80 \%)$.

\section{c. Support on The Achievement of Skill Learning Outcomes}

Civics teachers who effectively develop constructive learning, providing positive support to students' learning abilities in psychomotor, very high and high aspects of learning activities and participation $(85 \%)$ and high involvement in group learning $83 \%$. While the other aspects have high value and high on aspects: the ability to use communication technology for learning $(80 \%)$, using various resources to improve learning ability (78\%), the ability to complete tasks on time (80).

\section{DISCUSSION}

\section{The Characteristics of Civics Teachers Who Effectively Develop Constructive Learning}

The characteristic of an effective teacher is generally having to do with their competences to organize the process of learning in order to achieve the objective learning of learners. James Ko \& Pamela Samson (2014), formulize "Teacher effectiveness is generally referred to in terms of a focus on student outcomes and the teacher behaviours and classroom processes that promote better student outcomes". Particularly, the basic principle underlying constructivistic learning is that essentially all knowledge is constructed by subjects based on their own experience (John Dewey, 1916; Muijs \& Reynols, 2011, Glasersfeld, 1995).

Constructivists are convinced that learner as an individual have the ability to seek his own knowledge. Constructive learning is fundamental to support civics learning objectives, which is to develop rational and critical thinking ability and to play constructively in the life of citizenship democratically (essence of civics curriculum, 2006, 2013).

The findings of the research indicate that civics teachers develop constructive learning, implement constructive learning values effectively by considering the time available in learning activity to the greatest extent directed to the achievement of learners' involvement in the learning process. In the beginning of civics teachers' learning activities, generating learning spirit, building learning responsibilities, and developing the understanding about knowledge value which will be learned reflectively, exploring knowledge value that owned by the learners and connecting the new materials that are going to be learned. In order that learners to be directed in learning activities, the teachers show the process of learning activities that they are going to experience during the learning activities. In the core of learning activities, the teachers take role as facilitators, dynamists, and experts that provide the references of justifier of study value acquisition, so that the learners have convictions and satisfactions over their knowledge acquisition. The teachers develop their learning activities i.e. inquiries, that based on problems using scientific approach. 
Learning activities position the learners as active learners to observe/research and find the knowledge conceptually and factually through the process of observation, analysis, and evaluation, regarding the materials that contain problematic concepts and facts. The learners are conditioned to explore the materials being studied through media (image/book/video/internet) either conducted personally or through cooperative activities (teamwork). At the end of learning activities, teachers confirm the learners' learning outcomes, and ask reflection over the acquisition of their learning outcomes, conduct the assessment and give further guidance over their learners' learning activities.

Important things regarding the characteristics of teachers who are effectively developing constructive learning, are as follow:

\section{a. Creating an atmosphere that encourages learners to actively involved in learning process}

The important thing that teachers do is to conduct fun learning activities so they are motivated to actively participate in the learning process. Effective teachers consider learners' experiences and bring his idea to raise learners' thought on a given topic/theme that is being learnt. Teachers become motivators who generate the learners to pursue their learning objectives. Woolfolk (2008), stated that "motivation is an internal condition that generate, lead, and retain behaviour. Teachers build psychological closeness with learners, involve learners' experiences, assure the importance of the material learned and demonstrate the steps of learning activities during the learning activity, it is a positive effort to generate and direct learners to achieve optimal learning outcomes.

\section{b. Digging learners' ability in productive questioning}

Questioning ability is an instrument which shows that an individual is being involved in his thinking process. Through questioning ability, learners can expand their thoughts; connect the material that they have learnt contextually with their experiences and the real world or other theories they have known; dig their knowledge acquisition from the deepest till the highest. Banks (1990) explains “... help students learn these through process by skilfully asking appropriate question that lead students from simple to complex thinking tasks". Questioning ability is also a space for learners to achieve their cognitive satisfaction of a concept or value that they do not know wholly. A monumental Construktive figure is Piaget (1971), put the basic konstruktitifistik through his cognitive map in the aspect of intelligence as an integral part of every organism. The intelligence will change when the organism is biologically mature and already had experience. The individual uses the knowledge that is already known to decide the intellectual structure about his world. The intelligence power is formed by cognitive structure (schemata), which is formed since you were born (Piaget, 1971). The individual ability to construct the knowledge in praxis way is influenced by the factors of their existing thinking construct (Piaget) and the process of social interaction (Vygostky (1997). Regarding that, the cognitive structure of an individual should be actively involved, and the social values in its environment should be in its place to give the content of the structure of thinking in the process of learning. Teacher stimulation to explore learners' ability to ask questions is an environmental instrument that can influence their thinking construct maturity. 


\section{c. Developing thinking skills at the highest level (analyse, evaluate, and create); higher-order-thinking}

Teacher's activity in teaching is an intentional activity and should have meanings for the learners. Therefore, the level of achievement about the learners' thinking construct must be planned until it reaches the highest level of his cognitive. Anderson \& Krathwohl renew the cognitive taxonomy Bloom (1954) about the Taxonomy of Educational Objectives, that explains the cognitive aspects including: knowledge, comprehension, application, analysis, synthesis, and evaluation. Anderson \& Krathwohl (2001) revision shows that there is the knowledge dimension and the cognitive process dimension. Structure of the knowledge dimension include categories: factual knowledge, conceptual knowledge, procedural knowledge, and meta-cognitive knowledge. Structure of the cognitive process dimension includes categories: remember, understand, apply, analyze, evaluate and create.

The ability to analyze, evaluate and produce creative abilities is a high-level thinking skill. The cognitive process is also a demand of the national curriculum in 2013, which is also the reference of civics teachers in developing the learning process. Teachers Stimulation to develop thinking skills at high stages, is a process for the optimization of constructive learning.

\section{d. Building high sensitivity to the need of effective and productive learning}

The fundamental thing in constructive learning is how to educate learners to engage with the learning process. Learning is a mental process, a psychological process that involves an individual's positive attitude to the nature that they learn. When the individual perceives the importance of the object he is facing, he will feel the need and encourage himself to take the best action for the desired purpose. Similarly, the civics teachers who effectively develop constructive learning, build a high sensitivity to the need for effective and productive learning for learners. Stimulation of teacher learning is relevant to the demands of the national curriculum that requires civics learning to strengthen efforts to change the perspective of civics teachers to become more creative and innovative. Effective teachers are teachers who can create effective learning condition, which means creating conducive learning condition which support learners to do autonomy learning. Autonomy learning is learning process which involves learners in activities following the cycle of "Plan, Do, Study, Act" (Johnson, 2002). To support the fulfilment of that condition, it is important for teachers to know the needs of their learners so that they can learn effectively and productively.

\section{e. Developing learners' high curiosity}

Teachers' effectiveness in developing constructive learning may be pursued if teachers understand that the aspect of learners' 'curiosity' is a basic learners' need that should be fulfilled as their responsibility. Curiosity is a quality related to inquisitive thinking such as exploration, investigation, and learning, evident by observation in humans and other animals. Curiosity is heavily associated with all aspects of human development, in which derives the process of learning and desire to acquire knowledge and skill (en.wikipedia.org). Curiosity is an urge to know higher things because of initial stimulant which precedes. Building learners' curiosity is a constructive learning process, because it involves mind stimulation to interpret the knowledge being learned and build challenges to understand things 
that have not been known. Effective Civics Teachers in developing constructive learning, develop curiosity with high intensity. Developing curiosity has important value to encourage learners to be an active observer, building further learning challenges, giving high satisfaction in learning.

\section{f. Training learning ability to create original/new ideas}

Original/new ideas are characteristics of ideas which are creative. Thinking creatively means an ability of high-order-thinking which is characterised by the ability to think critical, evaluative, divergent, and elaborative. Thinking ideas which are original/new are ideas which do not imitate other people ideas, yet ideas which are borne by individual own reflective thinking. Anderson (2001) explain, “... in the create category emphasize originality (or uniqueness), ...can the term unique be used to describe the work of an individual student". Further explained also "the creative process can be broken into three phases: problem representation, solution planning, and solution execution" (Anderson (2001). This way of thinking is needed to create innovative works which will be helpful in solving problems. Among others, that the problem is always found in life, competitiveness in maintaining livelihood day by day is increasingly strong and complex, and essentially human beings have the potential to think to always find out about something that has not been known.

\section{g. Diagnosing learners' difficulties and showing a draft to find the solution}

Teachers are learners' preceptor in learning; that is why it is the duty of teachers to know what thing becomes an 'illness' in their learners' process of learning. Not all learners can optimally have reached their learning objectives because of some barriers; psychology, economy, and social, which surround learners while learning. The result shows that the effectiveness of civics teacher develop constructive learning, making the diagnosis of learners' learning difficulties as well as conveying a plan to find a solution. Teachers observe the learners' behavior in the learning process in the classroom, measure, assess and follow up on the achievement of student learning outcomes, providing guidance for the need to improve learning outcomes. Learners who have learning difficulties, explored with personal interviews and show solutions to the problems faced.

\section{h. Acting as facilitator in learning}

The effectiveness of teachers in constructive learning, managing learning activities based on heuristic approach. Teachers assess that learners are individuals who have potential and need assistance for optimal growth and development. The characteristics of effective civics teachers are: have an open and non-discriminatory attitude towards their learners; Have a positive attitude to advance the potential of learners optimally; Not easily emotional to face the problem of learners in the learning process; Have an interesting personality and build a harmonious sense of communication with learners; appreciate the learners' responses in learning activity no matter how small it is; Able to put themselves as educators, mentor and learning problem solver of their learners. Learning is empowering the learner and enabling the learner to reflect on realistic experiences (Muijs \& Reynolds, 2011). Teachers put themselves not as a source of knowledge but as a guide to find a way to acquire knowledge. 


\section{Support in Developing Constructive Based Learning Towards the Result of Leaning Civics}

Based on the regulation of the Ministry of Education and Culture Republic of Indonesia No. 20, 2016 regarding Graduate Competence Standard for Primary and Secondary Education. The learning objectives cover the development of the attitudes, knowledge, and skills aspects. The three domains of competence have different acquisition paths (psychological processes). Attitudes are gained through "accepting, running, appreciating, living, and practicing" activities. Knowledge is gained through activities of "remembering, understanding, applying, analyzing, evaluating, and creating". Skills are gained through "observing, asking, trying, reasoning, cheating, and creating" activities. In the context of Civics Education, the guidance of curriculum 2013, indicates that the development of civic, civics, citizenship and civic citizenship skills as a whole to become a character is organized by the development of instructional impacts, companion impacts, and civic cultures in an exciting, fun learning environment.

Teachers optimizing in making the development of constructive learning in civics subjects effective, have positive support to develop instructional effect, nurturant effect and civic culture in learning. Effective teachers are those who optimize the available time to achieve optimum learners' achievement of learning outcomes.

This study indicates that teachers who are effective in developing constructive learning can achieve the goals that must be realized in the achievement of learning, i.e. the fulfillment of cognitive, affective and high skills in the context of learning learners. Optimizing the success of learning is not purely because of teacher factors, there may be other factors that also influence, such as raw input of the learners themselves who are different intellectually, learning interest, hope, attitude and the social and cultural condition of learners' environment. Nevertheless, the results obtained in constructive learning get a very high score (grades 86-100) and high (71$85)$, which are obtained through the average scores of class groups on teachers being observed at $75 \%-83 \%$, are positive and included in a high category. These conditions indicate that the nature of teachers who develop constructive learning is effective towards the achievement of learners' learning ability.

\section{CONCLUSION}

Constructive learning has a great contribution to develop the purpose of civic education, remembering that it is substantively insist the learning to the involvement of individual internal potency as fundamental element in acquiring the result of learning. Constructive learning gives the learners a chance to learn actively, involving their minds, constructing/ building their own knowledge. This sort of approach is beneficial to the learners, because the process of learning becomes productive and has the impact towards the quality of their learning achievements. Constructive learning is in harmony with the civics learning objectives, that is developing the skill of rational and critical thinking as well as having a role constructively in the civic life democratically (the essence of civics curricular objective, 2006, 2013).

The result of the study at junior high school in Bandung city, to the teachers who effectively develop constructive learning, shows positive results for the 
development of learning objectives. Effective teachers develop constructive learning characterized by these efforts: create an atmosphere that encourages learners to be actively involved in the learning process; explore and develop high-level thinking skills (analyze, evaluate and create); build a high sensitivity to the need for effective and productive learning; develop curiosity and practice learning ability to produce original / new thinking ideas; and diagnose learning difficulties and act as a constructive learning facilitator. The effectiveness of effective teachers in developing constructive learning indicates high levels of student participation and learning in aspects of: concentration of learning process in the classroom; remembering the material being studied; delivering logical ideas/opinions; ability to connect the material contextually with daily life; ability to ask; achievement of learning outcomes; ability to express new/original ideas in problem solving.

\section{REFERENCES}

Anderson, W. Lorin \& Krathwohl, R. David, 2001, A Taxonomy for Learning Teaching and Assessing, A Revision of Bloom's Taxonomy of Educational Objectives, Addison Wesley Longman, Inc.

Banks, James. A. 1990. Teaching Strategies for Social Studies, Inquiry, Valuing and Decision Making, New York \& London: Longman.

Branson, S. Margaret. 1998. The Role of Civic Education a Forthcoming Education Policy Task Force Position Paper from the Communitarian Network, diakses di http:/ / civiced.org/papers/articles_role.html

Creswell, John W. 1998. Qualitative Inquiry and Research Design: Choosing Among. Five Tradition. London: SAGE Publications

Dewey, John. 1916. Democracy and Education, The Project Gutenberg eBook, http://www.gutenberg.org/852, 20 April 2013.

Glasersfeld, E. von. 1995. A constructivist approach to teaching. In: Steffe L. P. \& Gale J. (eds.) Constructivism in education. Erlbaum, Hillsdale: 3-15. Available at http://www.vonglasersfeld.com/

Johnson, B. Elaine, 2002, Contextual Teaching E Learning, California: Corwin Press Inc. Ko, James; Pamela Sammons, and Linda Bakkum. 2014. Effective Teaching. Berkshire: Education Development Trust.

Langeveld, M. J. 1980. Pedogogik Teoritis Sistematis. Bandung: Jemars.

Miles, Matthew B, Huberman, A Michael. 1992. Analisis Data Kualitatif. Jakarta. Universitas Indonesia Press.

Piaget, J. 1971, Biologi and Knowledge, Edinburg, UK: Eidenburg Press. Sugiyono, 2011. Metode Penelitian Kombinasi (Mixed Methods), Bandung: CV Afa Beta.

Woolfolk, Anita, 2008, Educational Psychology Active Learning Edition, 10th edition, Boston: Pearson Education Inc.

https:/ /en.wikipedia.org/wiki/Learning. 